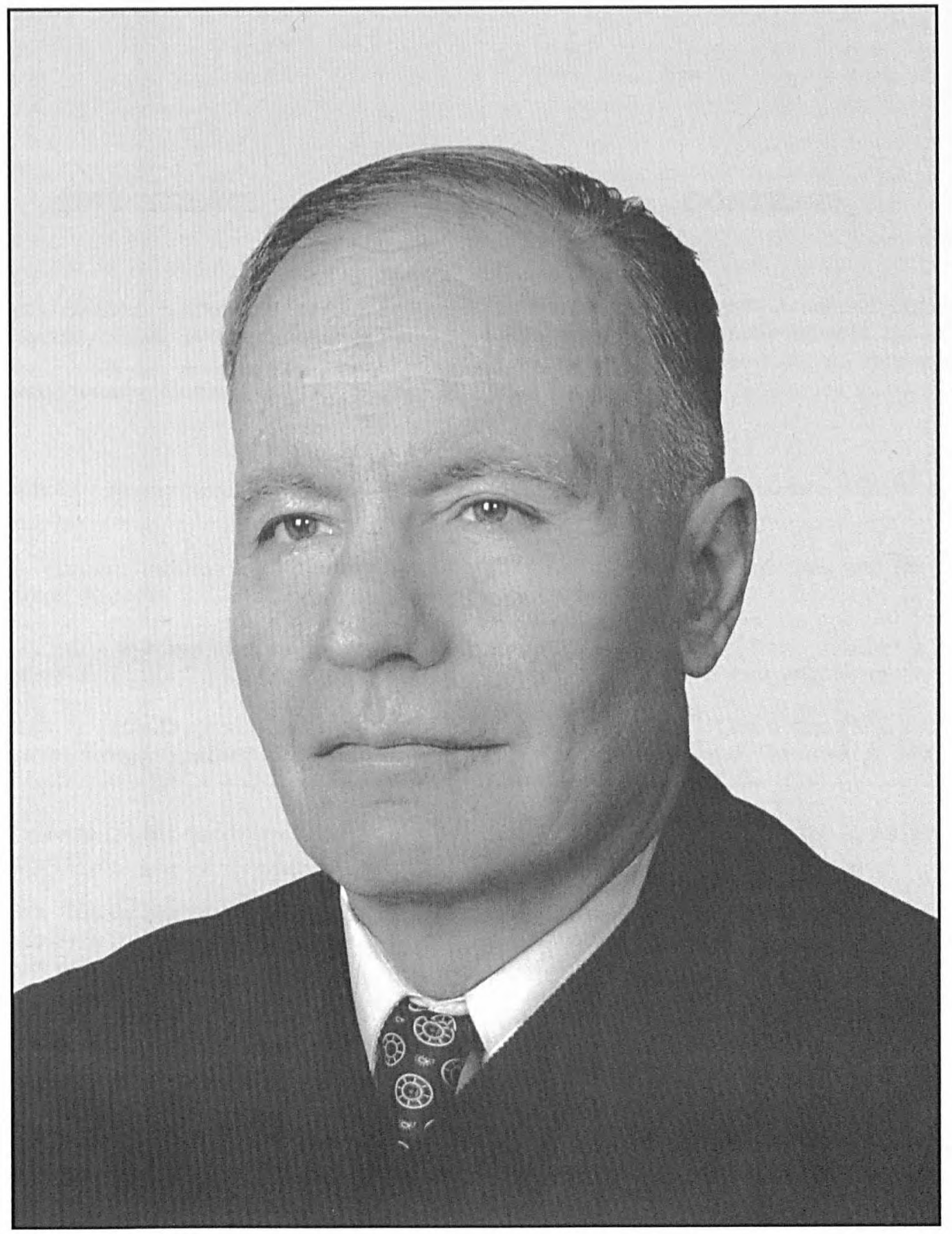

Profesor Marin Bachvarov 


\section{CHARAKTERYSTYKA DOROBKU
NAUKOWEGO, ORGANIZACYJNEGO \\ CHARAKTERYSTYKA DOROBKU
NAUKOWEGO, ORGANIZACYJNEGO I DYDAKTYCZNEGO PROFESORA MARINA BACHVAROVA}

\section{1. Życiorys naukowy}

W grudniu 2006 r. minęło 70 lat od dnia urodzin Marina Bachvarova. Niestety nie dożył On tej rocznicy, zmarł bowiem sześć miesięcy wcześniej 28 maja 2006 r. (LISZEWSKI 2006a, 2006b).

Marin Bachvarov urodził się 20 grudnia $1936 \mathrm{r}$. w Bułgarii, w mieście Biała, położonym w połowie drogi między Velkym Tyrnovem i Ruse, w rodzinie nauczycielki i prawosławnego proboszcza, co miało wpływ na Jego późniejsze życie. Szkoły ukończył w rodzinnym mieście i w 1954 r. został studentem geografii na Uniwersytecie im. św. Klimenta Ohridskiego w Sofii. Studia ukończył w 1959 r. z wynikiem celującym, co ułatwiło Mu wyjazd do Polski na studia doktoranckie. Studia te odbywał na Uniwersytecie Warszawskim, przygotowując pracę doktorską pod kierunkiem prof. dr. hab. Jerzego Kostrowickiego na temat funkcji zaopatrzeniowej strefy podmiejskiej Łodzi. Pracę obronił w 1964 r. uzyskując stopień doktora nauk geograficznych.

Po powrocie do Bułgarii związał się na stałe z uniwersytetem sofijskim, w którym pracował w latach 1965-1995. W tym czasie przeszedl całą drogę kariery naukowej. W 1974 r. odbył czteromiesięczną specjalizację $\mathrm{w}$ uniwersytecie moskiewskim, gdzie miał możliwość zapoznania się $\mathrm{z}$ dorobkiem naukowym geografów rosyjskich oraz osobistego poznania wielu geografów $\mathrm{z}$ republik wchodzących w skład b. ZSRR, z którymi utrzymywał kontakty naukowe przez wiele lat. W roku 1976 byl mianowany docentem, w 1991 r. obronił pracę habilitacyjną nt. Turysty$k a w$ środowisku osiedli, po czym został mianowany profesorem zwyczajnym tego uniwersytetu.

W 1980 r. Marina Bachvarova wybrano na kierownika Katedry Geografii Turyzmu w Uniwersy-

\section{PROF. MARIN BACHVAROV: ACADEMIC, ORGANIZATIONAL AND EDUCATIONAL ACHIEVEMENTS}

\section{Academic biography}

On 20th December 2006 Marin Bachvarov would have celebrated his $70^{\text {th }}$ birthday. Unfortunately he did not live to enjoy this anniversary having died six months earlier on 28 $8^{\text {th }}$ May 2006 (Liszewski, 2006a, 2006b).

Marin Bachvarov was born on $20^{\text {th }}$ December 1936 in Byala in Bulgaria, half way between Veliko Turnovo and Ruse, into a family of a teacher and an Orthodox priest, both of which influenced his later life. He went to schools in his home town and in 1954 entered St Kliment Ohridski University in Sofia from which he graduated in 1959 with distinction. This enabled him to move to Poland in order to complete his doctoral studies at Warsaw University where, under the supervision of Prof. Jerzy Kostrowicki, he prepared his $\mathrm{PhD}$ thesis on the topic of the supply function in the rural-urban fringe of Łódz. He defended the thesis in 1964, becoming a PhD in geography.

On returning to Bulgaria, he worked at Sofia University from 1965-95 and during this period went through all the stages of an academic career. In 1974 he specialized for four months at Moscow University, where he had an opportunity to learn about the academic output of Russian geography and make personal acquaintance with many geographers from the former USSR maintaining contacts with them over many years. In 1976 he became senior lecturer (docent) and in 1991 defended his habilitation thesis 
tecie im. św. Klimenta Ohridskiego w Sofii i funkcję tę pełnił przez 15 lat, czyli do końca 1994 r. W okresie tym był członkiem wielu komisji, towarzystw i redakcji oraz pełnil funkcje administracyjne, z których tylko przykładowo należy wymienić: przewodniczący Komisji Nauk o Ziemi przy Centralnej Komisji Akredytacyjnej Bułgarii, wiceprezydent Bułgarskiego Towarzystwa Geograficznego, prodziekan Wydziału Ekonomii uniwersytetu sofijskiego, redaktor naczelny czasopisma „Geografia".

Przez cały okres swojej działalności w Uniwersytecie im. św. Klimenta Ohridskiego w Sofii Profesor Bachvarov utrzymywal ścisłe kontakty z geografami zarówno z krajów bloku socjalistycznego, jak i z tzw. krajów zachodnich. Zwłaszcza te drugie ułatwił Mu Jego „mistrz” w zakresie geografii turyzmu i poprzednik w katedrze, prof. Lubomir Dinev.

Począwszy od roku akademickiego 1995/1996 Marin Bachvarov związał się z Uniwersytetem Łódzkim, gdzie podjął pracę początkowo jako profesor kontraktowy w Katedrze Geografii Miast i Turyzmu, a po przejściu w uniwersytecie sofijskim w 2000 r. na emeryturę został mianowany przez Ministra Edukacji i Szkolnictwa Wyższego RP na stanowisko profesora zwyczajnego w tej Katedrze.

Zmarł w Lodzi 28 maja 2006 r., po dziesięciomiesięcznej ciężkiej chorobie. Ciało zostało poddane kremacji, a prochy złożone na cmentarzu w Sofii.

Profesor Marin Bachvarov od 1970 r. był żonaty z Bojką Tichova, z która miał dwoje dzieci (córkę Marię i syna Piotra).

\section{Działalność naukowo-badawcza}

Działalność naukowa Profesora Marina Bachvarova zaowocowala około 150 opublikowanymi pracami (książki, podręczniki, artykuły, recenzje itd.) oraz znaczną liczbą referatów i wystapień na konferencjach, głównie międzynarodowych, z których tylko część została opublikowana. Podstawą oceny tej działalności jest bibliografia prac, która została sporządzona osobiście przez Profesora w Łodzi, na miesiąc przed śmiercią, kiedy nie miał możliwości dostępu do wcześniejszych swoich prac, zwłaszcza opublikowanych w latach 80 . XX w. w Bułgarii (bibliografia jest załącznikiem do tego opracowania).
Tourism in the Environment of Settlements and was appointed professor.

In 1980 Marin Bachvarov was elected the head of the Tourism Geography Department at St Kliment Ohridski University in Sofia, a position he held for 15 years until the end of 1994. In the same period he was a member of many commissions, societies and editorial boards, e.g. the chairman of the Earth Sciences Commission at the Bulgarian Central Accreditation Committee, vice-president of the Bulgarian Geographical Society, dean of the Economics Department at Sofia University, and editor of Geografia magazine.

During the time spent at St Kliment Ohridski University, Prof. Bachvarov maintained close contacts with geographers from both the socialist bloc and western countries. His 'master' in the field of tourism geography and his predecessor at the department, Prof. L. Dinev, helped him with contacts of the latter kind.

In 1995-6 Marin Bachvarov started work at the Department of Urban Geography and Tourism at the University of Łódz, first as a professor (Prof. kontraktowy) and later, after he retired from work at Sofia University in 2000, he was appointed full professor (Prof. zwyczajny) by the Minister of Education.

He died in Łódź after a ten-month struggle with a severe illness, on 28th May 2006. His body was cremated and buried in a cemetery in Sofia. Prof. Marin Bachvarov was married to Bojka Tichova and had two children (a daughter and a son).

\section{Research activity}

Prof. Marin Bachvarov's research activity resulted in over 150 publications (books, student textbooks, articles, reviews, etc.) and a considerable number of presentations and lectures at international conferences, only some of which were published. His activity can be judged on the basis of the bibliography of papers (not including his earlier work) published in the 1980s in Bulgaria which he prepared in Łódź one month before his death, (the bibliography is appended to this article). 
Zainteresowania naukowe Marina Bachvarova były bardzo rozległe i to zarówno w znaczeniu terytorialnym, jak i problemowym, co potwierdza analiza Jego dorobku. Najwięcej uwagi poświęcił jednak dwóm nurtom badawczym, które dotyczyły geografii turyzmu oraz szeroko pojmowanej geografii człowieka, z położeniem szczególnego akcentu na geografię polityczną.

Dorobek badawczy i publikacyjny Profesora w zakresie geografii turyzmu jest bardzo bogaty i tematycznie zróżnicowany. Pierwsze prace dotyczyły regionalizacji turystycznej i to zarówno całej Bułgarii (praca wykonana wspólnie z L. Dinevem w 1978 r.), jak i poszczególnych rejonów czy mikrorejonów turystycznych tego kraju, którym Autor poświęcił odrębne publikacje (rejon czarnomorski, samkowski, kivstendiłski, ruseński czy naddunajski).

Następny etap zaowocowal przygotowaniem i opublikowaniem współautorsko serii trzech podręczników z zakresu geografii turyzmu, które wydane zostały w języku bułgarskim: Geografia na turizma -1982 (współautor N. Apostołov), Turistčeska kartografia -1990 (współautor: B. Davidkov) oraz Antropogenni ustovja i resursi na otdiche $i$ turizma - 1990 (współautor: V. Marinov). Wzbogaciły one bardzo możliwości kształcenia akademickiego $w$ tej dyscyplinie geografii.

W drugiej połowie lat 90 . ubiegłego wieku i w początkach wieku XXI prace Profesora M. Bachvarova z zakresu geografii turyzmu dotyczyły ważnych rozważań o charakterze teoretycznym. To właśnie wtedy opublikował serię artykułów dotyczących m.in.: przestrzeni turystycznej (1998; współautor: S. Liszewski), nowego ujęcia regionu turystycznego (2004), europejskich miast kultury w kontekście rozwoju turystyki miejskiej (1999) oraz pracę terminologiczna, dotyczącą rozumienia turystyki i rekreacji (2005; współautor: E. Dziegieć).

Te trzy możliwe do wyróżnienia etapy w Jego dorobku publikacyjnym dotyczącym turystyki pokazują drogę rozwoju naukowego Marina Bachvarova w tym zakresie. Od konkretnej analizy regionalnej, przez podręczniki akademickie, do uogólnień i rozważań teoretycznych.

Drugi wyraźnie zaznaczający się nurt badawczy, który występował z różnym natężeniem w całej działalności naukowej Profesora, dotyczy szeroko pojmowanej geografii człowieka, jednak ze szczególnym ukierunkowaniem na geografię polityczną.
His body of work in the field of tourism geography is rich and varied. The first were works on tourist regionalization, both in the whole of Bulgaria (in cooperation with L. Dinev in 1978) and in its individual tourist regions or microregions which were discussed in separate publications (Black Sea, samkovsky, kivstendilsky, rusensky or the Danube regions).

The next stage resulted in a series of three student textbooks on tourism geography published in Bulgarian: Geografia na turizma - 1982 (co-author: N. Apostolov), Turistceska kartografia - 1990 (co-author: B. Davidkov) and Antropogenni uslovia i resursi na otdiche $i$ turizma - 1990 (coauthor: V. Marinov). They significantly improved academic education in this field of geography.

In the second half of the 1990s Prof. Marin Bachvarov presented important theoretical discussions concerning tourism geography. It was then that he published a series of articles on tourism space - 1998 (co-author: S. Liszewski), a new approach to the tourism region 2004, European cities of culture in the context of urban tourism development 1999, and terminology connected with tourism and recreation - 2005 (co-author: E. Dziegieć).

These three distinctive stages in Marin Bachvarov's publications show the progress in his academic development in the field of tourism: from regional analysis, through student textbooks, to generalisation and theoretical discussions.

Another direction, followed throughout his academic activity, was in human geography in a wider sense with a particular focus on political geography. He published his first significant work, a student textbook entitled Humanitarna geografia na Bulgaria, on this subject together with V. Bojadziev, P. Slavejkov and L. Caukova in 1992. In the same year he published an article entitled 'Electoral Geography in Bulgaria' pointing clearly to his geographical-political interests. A few years later he published $a$ terminological dictionary of geopolitics introducing order into basic concepts and definitions in 
Pierwszą znacząca pracę z tego zakresu opublikował wspólnie z V. Bojadżevem, P. Slavejkovem i L. Cankovą w 1992 r.; był to podręcznik zatytułowany Humanitarna geografia na Butgaria. W tym samym roku ukazał się artykuł pt. „Geografia wyborcza w Bułgarii” wskazujący bardzo wyraźnie na geograficzno-polityczne zainteresowania Autora. W kilka lat później (1999) opublikował słownik terminologiczny geopolityki, porządkując na gruncie języka bułgarskiego podstawowe pojęcia i definicje $\mathrm{z}$ tej dziedziny wiedzy. Odsyłając czytelnika do wykazu pozostałych publikacji nie można jednak nie wspomnieć o wydanym w języku polskim kompendium terminologicznym z zakresu geografii politycznej i geopolitycznej (2002; wspólautor: A. Suliborski).

Marin Bachvarov z dużym zainteresowaniem, ale również i znawstwem, obserwował wydarzenia polityczne zachodzące na Półwyspie Bałkańskim. Komentował je na licznych konferencjach i publikował w czasopismach naukowych oraz $w$ wydawnictwach publicystycznych. Nie bez znaczenia była Jego znajomość języka serbskiego, ułatwiająca $\mathrm{Mu}$ dostęp do materiałów i literatury.

Znacząca część dorobku naukowego Profesora opublikowana została w Polsce zarówno w języku polskim, jak i angielskim (ok. 35 pozycji), w tym kilkanaście (17) prac ukazało się w czasopiśmie naukowym Turyzm. Warto tu przypomnieć, że dwie pierwsze swoje prace naukowe opublikowal w Przegladzie Geograficznym, ukazującym się w Warszawie. Były to: „Hutnictwo żelaza i metali nieżelaznych w Bułgarii” (1962, z. 2) oraz „Stopień urbanizacji Bułgarii" (1965, z. 4) - wspólnie z M. Miechevem. Również ostatnia publikowana za Jego życia praca, pt. „Osiedla zamknięte - getta z wyboru” (2006), ukazała się w Łodzi w tomie zawierającym materiały z XVIII Konwersatorium Wiedzy o Mieście.

Profesor M. Bachvarov publikował swoje prace w kilku językach (bułgarski, polski, angielski, rosyjski, francuski i niemiecki), co zapewniało ich odbiór wśród geografów wielu krajów.

\section{Działalność dydaktyczna}

Profesor Marin Bachvarov będąc przez 40 lat czynnym nauczycielem akademickim prowadził zajęcia dydaktyczne na różnych kierunkach studiów i na różnych uczelniach. Jego zainteresowania badawcze korespondowały z zajęciami dydaktycznymi. Prowadził wykłady m.in. z zakresu geo-
Bulgarian. A terminological compendium of political and geopolitical geography published in Polish must not be ignored (co-author: A. Suliborski)

Marin Bachvarov was very interested and knowledgeable on political events taking place in the Balkans, commenting on them at different conferences and in a variety of academic publications. His knowledge of Serbian was important as this gave him easier access to sources and literature.

A considerable part of his academic output was published in Poland, both in Polish and English (about 35 titles), including several (17) pieces which appeared in the Turyzm academic journal. It is worth mentioning at this point that his first two works had been published in The Geographical Review in Warsaw: 'Ferrous and non-ferrous industry in Bulgaria' (1962) and 'The Urbanization of Bulgaria' (co-author: M. Mieczev). His last work published during his lifetime was 'Closed Estates - Ghettos of Choice' (2006) appearing in Łódź, in the volume on the $18^{\text {th }}$ Knowledge about the City Conversatory.

Prof. Bachvarov's work was published in several languages (Bulgarian, Polish, English, Russian, French and German) and became known among geographers from many countries.

\section{Educational activity}

An academic teacher for 40 years, Prof. Marin Bachvarov held classes corresponding to his research interests with students at different university departments and at various universities. He gave lectures on regional geography, tourism geography, political geography and geopolitics (especially concerning the Balkans), and social and cultural geography (including the tourist use of cultural heritage). For many years he taught geography students at St Kliment Ohridski University in Sofia, the New Bulgarian University in Sofia and the University in Veliko Tyrnovo. From 1995 led classes for students of tourism geo- 
grafii regionalnej, geografii turyzmu, geografii politycznej i geopolityki (szczególnie Półwyspu Bałkańskiego), geografii społecznej i geografii kultury (w tym turystyczne użytkowanie dziedzictwa kulturowego). Wykladał przez wiele lat dla studentów na kierunku geograficznym w Uniwersytecie im. św. Klimenta Ohridskiego w Sofii oraz w Nowym Bułgarskim Uniwersytecie w Sofii i Uniwersytecie w Velkym Tyrnovie. Od 1995 r. prowadził zajęcia na kierunku geografia turyzmu i hotelarstwa w Uniwersytecie Lódzkim oraz w filii tego uniwersytetu w Tomaszowie Mazowieckim. Wykładal również na geografii w Uniwersytecie Wrocławskim. Poza tym prowadził zajęcia dla studentów na kierunku filozoficznym uniwersytetu sofijskiego oraz na kierunku turystyka i rekreacja w Wyższej Szkole Turystyki i Hotelarstwa w Lodzi, w Wyższej Szkole Przymierza Rodzin w Warszawie i w Akademii Wychowania Fizycznego we Wroclawiu.

Profesor Bachvarov jest autorem i współautorem kilku podręczników akademickich i artykułów dydaktycznych.

Począwszy od $2001 \mathrm{r}$. prowadził seminarium magisterskie na specjalności turystyka i hotelarstwo w Katedrze Geografii Miast i Turyzmu Uniwersytetu Łódzkiego. Do czasu swojej choroby wypromowal ogólem 35 magistrów geografii w specjalności geografia turyzmu i hotelarstwa (2003 17, 2004-10 i 2005 - 8 osób).

\section{Działalność międzynarodowa}

Podstawą aktywności międzynarodowej Profesora Marina Bachvarova była znajomość kilku języków (bułgarski, polski, angielski, rosyjski, francuski i serbski), zainteresowania badawcze oraz znajomość wielu geografów zarówno z bloku krajów socjalistycznych, jak i krajów Europy Zachodniej. Pierwsze kontakty naukowe nawiązał przy okazji spotkań Grupy Roboczej Geografii Turyzmu powołanej przez Międzynarodową Unię Geograficzną w 1972 r. Grupa, która w 1976 r. została podniesiona do rangi Komisji Geografii Turyzmu i Wypoczynku MUG (BACHVAROV 2002), jedno ze swoich posiedzeń odbyła w Varnie w Bułgarii (1980 r.), co umożliwiło M. Bachvarovowi nawiązanie bliższych kontaktów z międzynarodowym gronem geografów. Od tego czasu stał się częstym uczestnikiem spotkań i konferencji międzynarodowych, a w latach 1980-1984, 1988-1992 i 2000- graphy and hotel management at the University of Łódż and its branch in Tomaszów Mazowiecki while also giving lectures at the Geography Department at the University of Wrocław. In addition, he ran classes for philosophy students at Sofia University, tourism and recreation students at the Higher School of Tourism and Hotel Management in Łódź, at the Wyższej Szkole Przymierza Rodzin in Warsaw and at the Academy of Physical Education in Wroclaw.

Prof. Bachvarov is the author and coauthor of several student textbooks and articles on teaching.

From 2001, he conducted a tourism and hotel management M.A. seminar at the Urban Geography and Tourism Department at the University of Łódź. Before his illness, he had promoted 35 masters degrees in the field of tourism geography and hotel management (2003 17, 2004 - 10, and 2005 - 8).

\section{International activity}

Prof. Marin Bachvarov based his international activity on a knowledge of several languages (Bulgarian, Polish, English, Russian, French and Serbian), his academic interests and personal acquaintance with many geographers both from the socialist bloc and the countries of Western Europe.

He made his first contacts during meetings of the Tourism Geography Working Group, set up by the International Geographical Union in 1972. This group, which in 1976 was raised to the rank of the Geography of Tourism and Leisure Commission (BACHVAROV 2002), held one of its meetings in Varna, Bulgaria (1980) which enabled him to make closer contacts with an international circle of geographers. From that time he became a regular participant of international meetings and conferences; in 1980-4, 1988-92 and 2000-4 he was a member of the commission which operated within the International Geographical Union 
2004 był członkiem rzeczywistym lub członkiem korespondentem Komisji, która pod różnymi nazwami działała w Międzynarodowej Unii Geograficznej. Profesor przez cały ten czas (25 lat) był jednym z najbardziej aktywnych członków tej Komisji.

W latach 1990-1994 Marin Bachvarov był koordynatorem międzynarodowego projektu TEMPUS pt. „Udoskonalenie zarządzania turystyką i hotelarstwem”, który był realizowany pod kierownictwem Instytutu Technologicznego w Dublinie. Brał też udział w latach 1992-1994 w bułgarsko-holenderskim projekcie TEMPUS dotyczącym integracji mniejszości narodowych w Bułgarii.

Począwszy od 1990 r. bardzo aktywnie uczestniczył w pracach i kongresach nowej międzynarodowej organizacji The Association for Tourism and Leisure Education (ATLAS). Dzięki Jego staraniom kolejna międzynarodowa konferencja tej organizacji odbyła się we wrześniu 2006 r. w Polsce (już po Jego śmierci), a jej organizatorem była Katedra Geografii Miast i Turyzmu Uniwersytetu Łódzkiego.

Liczne kontakty naukowe i akademickie Profesora owocowały zaproszeniami na wykłady do wielu uniwersytetów zagranicznych. Wykłady prowadził m.in. na uczelniach: Paryż VII, Paryż X, Ecole Normale Superieure Fontenay-aux-Roses, Angers, uniwersytet moskiewski, University of Quebec-Rimouski, Mińsk (Białoruś), Coimbra, Savonlinna, Kaliningrad, Lund, Leeuwarden, Greifswald, Smoleńsk i Thessaloniki.

Profesor Marin Bachvarov był osobą otwartą na świat, który obserwował oczami geografa, analizując zachodzące procesy i dokonujące się zmiany. Starał się swoje spostrzeżenia przekazywać innym, inspirując do dyskusji i podejmowania badań naukowych. Był człowiekiem skromnym i pracowitym, bardzo zaangażowanym $\mathrm{w}$ badania naukowe, które były celem Jego życia. Otwartość na świat i ludzi pozwoliła Mu znaleźć w Polsce swoją drugą ojczyznę. Czuł się wśród nas dobrze, na co wskazuje fakt, że przeniósł do Łodzi swój „dom”, sprowadzając tu Żonę. My również ceniliśmy Go jako kolegę i jako osobę, która odgrywała w naszym gronie rolę inspiratora pomysłów badawczych. Wraz z Jego odejściem zakończył się pewien etap $w$ rozwoju geografii turyzmu w Europie. To właśnie On był jednym z nielicznych, którzy swoją osobą i osobowością łączyli geografów turyzmu z Zachodu i Wschodu Europy. under different names. Throughout these 25 years he was one of its most active members.

In 1990-4 Marin Bachvarov was the coordinator of an international TEMPUS project 'Improving Tourism and Hotel Services', supervised by the Technology Institute from Dublin. In 1992-4 he also took part in the Bulgarian-Dutch TEMPUS project concerning national minorities in Bulgaria.

Starting from 1990 he worked very actively with a new international organization, the Association for Tourism and Leisure Education (ATLAS). It was due to his efforts that the latest ATLAS conference was held in September 2006 in Poland (after his death), and organized by the Urban Geography and Tourism Department at the University of Łódż.

His numerous academic contacts resulted in invitations to give lectures at many foreign universities. Let us quote here only some: Paris 7, Paris 10, Ecole Normale Superieure Fontenay-aux-Roses, Angers, Moscow University, University of Quebec-Rimouski, Minsk, Coimbra, Savonlinna, Kaliningrad, Lund, Leeuwarden, Greifswald, Smolensk and Thessaloniki.

Prof. Marin Bachvarov was open to the world and he observed it as a geographer, analyzing its ongoing processes and changes. He tried to pass on these observations to others, inspiring discussion and research. He was a modest, hardworking man, very much involved in research the main purpose in his life. His openness to the world and to people let him find his second homeland in Poland. He felt at home here, bringing his wife and settling in Łódź. We appreciated him as a colleague and a person who inspired us to come forward with original research ideas. His departure brought an end to a certain stage in the development of tourism geography in Europe as he was one of the few who brought tourism geographers together from the west and east of the continent. 
Wśród otrzymanych odznaczeń, nagród i wyróżnień cenił najbardziej dwa: Medal św. św. Cyryla i Metodego, przyznany Mu przez Rząd Bułgarski, oraz Złotą Odznakę Polskiego Towarzystwa Geograficznego.

\section{BIBLIOGRAFIA - BIBLIOGRAPHY}

BACHVAROV, M., 2002, Prof. Bernard Barbier - przewodniczacy Komisji Geografii Turyzmu MUG. 1980-1992, Turyzm 12/ 2, s. 17-23.

\section{Stanisław Liszewski}

Uniwersytet Łódzki

Katedra Geografii Miast i Turyzmu

90-142 Łódż, ul. Kopcińskiego 31
LISZEWSKa, S., 2006a, Wspomnienie pośmiertne. Marin Bachvarov (1936-2006), Turyzm 16/2, s. 207-210.

Liszewski, S., 2006b, Marin Bačvarov. 1936-2006, Przeglad Geograficzny 78/3, s. 608-610.
Among all the awards and distinctions he received, the two he valued most were the SS Cyril and Methodius Medal by the Bulgarian government and the medal of the Polish Geographical Association (Polskie Towarzystwo Geograficzne). 